\title{
BIMBINGAN KONSELING BAGI PEREMPUAN KORBAN KEKERASAN DALAM RUMAH TANGGA DI LRC-KJHAM SEMARANG
}

\author{
M. Asasul Muttaqin, Ali Murtadho, Anila Umriana \\ Universitas Islam Negeri (UIN) Walisongo Semarang \\ e-mail: anilaumriana@yahoo.co.id
}

\begin{abstract}
Abstrak
Kekerasan terhadap perempuan (istri) yang terjadi di lingkungan keluarga tidak terlepas dari adanya ketimpangan gender yang menjadi salah satu sebab terjadinya KDRT. Di Jawa Tengah, salah satu lembaga yang memiliki konsen dalam penanganan kasus KDRT adalah LRC KJHAM. Pelayanan bimbingan konseling individu dan support group bagi korban KDRT yang diberikan oleh LRC-KJHAM bersifat integral dan menimbulkan perubahan yang signifikan dari perubahan sikap dan psikologis perempuan korban kekerasan dalam rumah tangga. Melalui bimbingan konseling tersebut para individu (korban) mampu menyadari bahwa dapat mengatasi masalahnya sendiri dan sadar bahwa mereka secara bersama dapat berjuang untuk mengatasi masalah yang mereka alami.
\end{abstract}

Kata Kunci: Bimbingan Konseling; korban KDRT; LRCKJHAM

\section{A. Pendahuluan}

Pernikahan merupakan tonggak awal yang sangat menentukan kehidupan keluarga sekaligus sebagai pintu gerbang menuju terbentuknya sebuah keluarga sakinah. Pernikahan merupakan proses bersatunya dua orang pada suatu ikatan yang di dalamnya terdapat komitmen dan bertujuan untuk membina rumah tangga dan meneruskan keturunan. Salah satu tujuan dalam pernikahan adalah terwujudnya kebahagiaan lahir dan batin, dan terciptanya ketentraman dan kedamaian hidup berumah tangga. Namun pada kenyataanya, tidak semua pernikahan berjalan dengan baik dan mencapai tujuan tersebut. Salah satu permasalahan yang muncul dalam rumah tangga adalah adanya tindak kekerasan.

Kekerasan terhadap perempuan yang terjadi di masyarakat, termasuk di lingkungan keluarga, tidak terlepas dari adanya ketimpangan gender yang 
menjadi salah satu sebab terjadinya penindasan terhadap perempuan, seperti subordinasi yang memandang perempuan sebagai mahluk yang lebih rendah dibanding laki-laki. Selain itu, tentu masih ada faktor lain yang menjadi pemicunya. Salah satunya dapat pula disebabkan oleh adanya pemahaman agama yang bias gender sehingga dijadikan legitimasi tindakan kekerasan terhadap istri. ${ }^{1}$ Menurut UU No. 23 tahun 2004 yang mengatur tentang penghapusan kekerasan dalam rumah tangga, yang menyebutkan setiap orang dilarang melakukan kekerasan dalam rumah tangga terhadap orang yang dalam lingkup rumah tangganya, dengan cara kekerasan fisik, kekerasan psikis, kekerasan seksual, dan pelantaran rumah tangga.

Salah satu cara untuk menghapus tindak kekerasan dalam rumah tangga yang terjadi, Pemerintah Kota Semarang melakukan upaya perlindungan dan pendampingan terhadap korban yang menjadi korban. Agar upaya tersebut dijalankan menyeluruh sampai ke tingkat masyarakat yang paling bawah, Pemerintah Kota Semarang menjalin kerja sama dengan LSM/NGO yang peduli pada perwujudan keadilan dan kesetaraan gender, salah satunya Legal Resource Center - Keadilan Jender dan Hak Asasi Manusia (LRC-KJHAM). LRC-KJHAM berdiri untuk memajukan nilai dan prinsip keadilan jender dalam proses perumusan dalam kebijakan dan selalu bekerja untuk membangun, melindungi dan meningkatkan hak asasi perempuan.

Data dalam laman website Komnas Perempuan disebutkan bahwa Kekerasan terhadap Perempuan (KTP) yang dimuat dalam Catatan Tahunan (CATAHU) Komnas Perempuan Tahun 2013 bersumber dari data kasus yang ditangani dan diterima dari sejumlah 195 lembaga mitra layanan yang tersebar dari seluruh provinsi di wilayah Indonesia atau berkisar 54\% dari total 361 lembaga layanan yang dikirimi formulir pendataan, serta pengaduan langsung ke Komnas Perempuan. Jumlah kasus KTP (kekerasan terhadap perempuan) 2013 sebesar 279.688 sebagian besar data tersebut diperoleh dari data kasus/perkara yang ditangani oleh PA, yaitu mencapai 263.285 kasus atau berkisar 94\%. Sisanya sejumlah 16.403 kasus atau berkisar $6 \%$ bersumber dari 195 lembaga-lembaga mitra layanan yang merespon dengan mengembalikan formulir pendaftaran yang

${ }^{1}$ Sri Suhandjati, Islam Menentang Kekerasan terhadap Istri, (Yogyakarta: Gamma Media, 2004), h. vi. 
dikirimkan oleh Komnas Perempuan. Pola kekerasan terhadap perempuan yang ditangani oleh lembaga mitra layanan antara lain: kekerasan terjadi di ranah personal sejumlah 11.719 (71\%); kekerasan yang terjadi di ranah komunitas sejumlah 4.679 (29\%), dan kekerasan ranah negara adalah 5 kasus; empat kasus berkaitan dengan kriminalisasi korban dalam konflik SDA di Sumatra Barat, dan satu kasus hambatan dalam proses hukum ketika melaporkan di ranah komunitas yang terjadi di DKI. Bentuk KDRT/RP mencakup kekerasan terhadap isteri (KTI 64\%), kekerasan dalam pacaran (KDP 21\%), kekerasan terhadap anak perempuan (KTAP $7 \%$ ), kekerasan dari mantan suami (KMS 1\%), kekerasan mantan pacar (KMP 1\%), dan kekerasan terhadap pekerja rumah tangga (PRT, ada 23 kasus). ${ }^{2}$

Hasil monitoring kasus kekerasan terhadap perempuan di Jawa Tengah tahun 2013, mengindentifikasi adanya peningkatan kasus kekerasan terhadap perempuan dibandingkan dengan tahun 2012. Pada tahun 2013, LRC-KJHAM telah mencatat 460 kasus kekerasan terhadap perempuan di Jawa Tengah. Sementara pada tahun 2012, tercatat 408 kasus kekerasan terhadap perempuan. Kasus KDRT yang tercatat oleh LRC-KJHAM pada tahun 2013, tercatat ada 201 kasus KDRT. Sementara pada tahun 2012 tercatat 146 kasus KDRT dan tahun 2011 tercatat 197 kasus KDRT. Dengan demikian kasus KDRT yang terjadi di jawa tengah pada tahun 2013, menunjukkan peningkatan dibandingkan dengan kasus KDRT yang terjadi pada tahun 2011 dan 2012. Tahun 2013, LRC-KJHAM mencatat setidaknya ada 201 kasus KdRT di Jawa Tengah yang tersebar di 21 Kabupaten atau Kota di Jawa Tengah. Kota Semarang sendiri tercatat sebagai daerah dengan jumlah kasus KdRT yang tertinggi yaitu 144 kasus. ${ }^{3}$

Didirikannya LRC-KJHAM adalah untuk memperkuat akses dan kontrol perempuan miskin, marjinal dan rentan terhadap sumberdaya hukum dan hak asasi manusia. Tujuan tersebut dicapai dengan melakukan pendampingan dan bantuan hukum yang berkeadilan jender, melakukan kerja-kerja pembaharuan hukum dan kebijakan untuk memperbaiki status

${ }^{2}$ Www.komnasperempuan.or.id/2004/11catatan-tahunan-komnas-perempuan-20014kegentingan-kekera san-seksual-lemahnya-upaya-penanganan-negara/ di akses tanggal 15 Desember 2014, pukul 20.30.

${ }^{3}$ Laporan Tahunan LRC-KJHAM, 2013, h. 12. 
hukum perlindungan dan pemenuhan hak asasi, melakukan kerja-kerja pendidikan hak asasi untuk mempromosikan keadilan jender dan hak asasi perempuan, melakukan penelitian, monitoring dan pendokumentasian pelanggaran hak asasi perempuan untuk memperkuat kerja-kerja hak asasi guna mendorong perbaikan status kebijakan realisasi hak asasi perempuan di Indonesia, dan melakukan kampanye untuk mempromosikan hak asasi perempuan dan perbaikan kebijakan.

Sebagai Lembaga Bantuan Hukum untuk Keadilan Jender dan Hak Asasi Manusia, LRC-KJHAM berdiri untuk memajukan nilai-nilai dan prinsip keadilan jender dalam proses perumusan kebijakan, dan selalu bekerja untuk membangun, melindungi dan meningkatkan hak asasi perempuan. Serta menyediakan layanan bantuan hukum, support psikologi untuk perempuan dan anak-anak, juga fokus pada pendidikan, penelitian, advokasi kebijakan dan pendokumentasian pelanggaran hak asasi perempuan.

Kenyataan akan adanya problem yang berkaitan dengan pernikahan dan kehidupan keluarga, yang seringkali tidak bisa diatasi sendiri oleh yang terlibat dengan masalah tersebut, menunjukkan bahwa diperlukan adanya konseling dari pihak lain untuk turut membantu mengatasi permasalahan yang dihadapinya. Selain itu, kenyataan bahwa kehidupan pernikahan dan keluarga itu selalu saja ada problemnya, menunjukkan pula perlunya adanya bimbingan Islam mengenai pernikahan dan pembinaan kehidupan

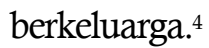

\section{B. Bimbingan dan Konseling Islam}

Secara etimologis kata bimbingan merupakan terjemahan dari bahasa Inggris "guidance". Kata "guidance' adalah kata dalam bentuk kata benda yang berasal dari kata kerja "to guide" artinya menunjukkan, atau menuntun orang lain menuju ke jalan yang benar. ${ }^{5}$ Bimbingan merupakan bantuan yang diberikan oleh seorang pembimbing kepada individu atau kelompok individu dari semua jenis dan umur baik yang telah memiliki problem

${ }^{4}$ Faqih, Aunur Rahim, Bimbingan dan Konseling Dalam Islam, Yogyakarta: UII Press, 2004, hlm. 82

${ }^{5}$ Samsul Munir Amin, Bimbingan dan Konseling Islam, (Jakarta: Amzah, 2010), h. 3. 
maupun yang belum untuk mencegah atau mengatasi kesulitan hidupnya agar individu atau sekelompok individu itu memahami dan mengerti dirinya dan mampu membuat keputusan sendiri dalam menghadapi masalahnya sesuai dengan kemampuannya, sehingga tercapai kebahagiaan hidup sebagai makhluk individu maupun makhluk sosial. ${ }^{6}$

Jones mengatakan:

"Guidance is the assistance given to individuals in making intelligent choices and adjustment. It is based on the democratic principle that it is the duty and the right of every individuals to choose his own way of life in so far as his choice does not interfere with the right of other. Guidance is an integral part of education and is centered directly upon this function. Guidance does not make choice for individuals, it help them make their own choice in such a way us to promote or stimulate the gradual development of the ability to make decisions independently without assistance from others". 7

Istilah konseling berasal dari kata "counseling" dari kata dalam bentuk kata benda dari kata kerja "to counsel" secara etimologis berarti "to give advice" atau memberikan saran dan nasihat. ${ }^{8}$ Konseling adalah bantuan yang diberikan oleh seorang ahli (konselor) kepada seorang klien atau sekelompok klien untuk mengatasi problemnya dengan jalan wawancara dengan maksud agar klien atau sekelompok klien tersebut mengerti jelas tentang problemnya sendiri sesuai dengan kemampuannya mempelajari saran-saran yang diterima dari konselor. ${ }^{9}$

Menurut Anwar Sutoyo, hakikat bimbingan dan konseling Islam adalah upaya membantu individu belajar mengembangkan fitrah dan atau kembali kepada fitrah, atau kembali kepada fitrah, dengan cara memberdayakan (empowering) iman, akal, dan kemauan yang dikaruniakan Allah. ${ }^{10}$ Konseling Islami adalah aktivitas yang bersifat membantu, dikatakan membantu karena pada hakikatnya individu sendirilah yang perlu

'Sayekti Pujosuwarno,. Bimbingan dan Konseling Keluarga, (Yogyakarta: Menara Mas Offset, 1994), h. 82.

${ }^{7}$ Jones, Principles of Guidance, (New Delhi: Mc Graw Hill Publishing), 1979, h. 3.

${ }^{8}$ Samsul Munir Amin, Bimbingan dan Konseling Islam, (Jakarta: Amzah, 2010), h.10.

'Sayekti Pujosuwarno, Bimbingan dan Konseling Keluarga, h. 83.

${ }^{10}$ Anwar Sutoyo, Bimbingan dan Konseling Islam (Teori dan Praktif), (Yogyakarta: Pustaka Pelajar, 2013), h. 22. 
hidup sesuai tuntutan Allah (jalan yang lurus) agar selamat. Karena posisi konselor bersifat membantu, maka konsekuensinya individu sendiri yang harus aktif belajar memahami dan sekaligus melaksanakan tuntutan Islam (al-Qur'an dan sunah rasul-Nya). Pada akhirnya diharapkan agar individu selamat memperoleh kebahagiaan sejati di dunia dan akhirat, bukan sebaliknya kesengsaraan dan kemelaratan di dunia dan akhirat.

Konseling islami adalah aktivitas yang bersifat membantu. Dikatakan membantu karena pada hakikatnya individu sendirilah yang perlu hidup sesuai tuntunan Allah (jalan yang lurus) agar mereka selamat. Karena posisi konselor bersifat membantu, maka konsekuensinya individu sendiri yang harus aktif belajar memahami dan sekaligus melaksanakan tuntunan Islam (al-Qur'an dan sunah rasul-Nya). Pada akhirnya diharapkan agar individu selamat dan memperoleh kebahagiaan yang sejati di dunia dan akhirat, bukan sebaliknya kesengsaraan dan kemelaratan di dunia dan akhirat. ${ }^{11}$

Bimbingan konseling Islam memiliki tujuan yang sama dengan bimbingan konseling, yaitu sama-sama ingin membantu sesama manusia agar keluar dari berbagai kesulitan dengan kekuatan sendiri. Perbedaan mendasar terletak pada bimbingan konseling Islam senantiasa mengaitkan dengan asas agama Islam. Konsep bimbingan dan konseling Islam bersandar kepada kemutlakan kuasa Allah dan kemaksimalan usaha sendiri. ${ }^{12}$ Bagi keluarga yang terlibat tindak kekerasan baik sebagai pelaku atau korban perlu diberi konseling untuk membantu menyadarkan bahwa tindak kekerasan dalam rumah tangga harus dihapuskan, karena telah melanggar hak-hak kemanusiaan, baik dihadapan manusia maupun dihadapan tuhan. Sasaran konseling adalah keluarga dimana terjadi kekerasan dalam rumah tangga, khususnya istri yang mengalami tindak kekerasan dari suami, mencakup: (1) kekerasan fisik, seperti pemukulan, penyiksaan yang mengarah kepada organ kelamin (genital mutilation), (2) pemaksaan alat kontrasepsi tertentu yang mengakibatkan kesakitan, seperti sterilisasi (end forced sterilization), (3) kekerasan ekonomi, seperti menelantarkan keluarga; (4) kekerasan psikologis, seperti mengintimidasi, mendiskreditkan, mengusir, berbicara kasar dan menyakitkan secara terus menerus.

\footnotetext{
${ }^{11}$ Ibid.

${ }^{12}$ Isep Zainal Arifin, Bimbingan Penyuluhan Islam. (Jakarta: Raja Grafindo Persada, 2009), h. 12.
} 
Karakteristik klien yang perlu mendapat layanan konseling adalah isteri beserta anggota keluarganya, antara lain: (1) istri yang mengalami tindak kekerasan fisik, ekonomi, maupun psikologis, (2) klien yang telah mendapat bantuan medis dari tindakan kekerasan fisik untuk mendapat pemulihan kesehatan psikologis, (3) klien yang akan atau sedang menghadapi proses bantuan hukum, (4) klien yang mengalami trauma psikis, frustasi, cemas, dan depresi akibat mengalami kekerasan fisik dan/atau psikis. ${ }^{13}$

\section{Kekerasan dalam Rumah Tangga}

Kekerasan dalam rumah tangga merupakan perilaku yang dipelajari yang mencakup perbuatan dan perkataan kasar kepada seseorang dengan menggunakan ancaman, kekuatan dan kekerasan fisik, seksual, emosional, ekonomi, dan lisan. Definisi yang lebih umum bahwa kekerasan rumah tangga merupakan serangan yang menimbulkan luka fisik atau kematian terhadap anggota keluarga. Semua anggota rumah tangga, baik perempuan maupun laki-laki memungkinkan dapat menjadi pelaku atau korban kekerasan rumah tangga. Demikian juga kekerasan pasangan, yaitu antara suami istri. Namun demikian, perempuan umumnya cenderung lebih banyak menjadi korban daripada sebagai pelaku, dan sebaliknya laki-laki lebih banyak menjadi pelaku daripada sebagai korban kekerasan bila ditinjau dari kekuatan fisik, ekonomi, status sosial yang telah terkonstruksi secara kultural. ${ }^{14}$

Pengertian kekerasan dalam rumah tangga (KDRT) menurut undangundang no 23 tahun 2004 adalah setiap perbuatan terhadap seseorang terutama perempuan, yang berakibat timbulnya kesengsaraan atau penderitaan secara fisik, seksual, psikologis dan penelantaran rumah tangga termasuk ancaman untuk melakukan perbuatan, pemaksaan atau perampasan kemerdekaan secara melawan hukum dalam lingkup rumah tangga. ${ }^{15}$

Di Indonesia saat ini, kekerasan dalam rumah tangga telah mendapatkan perhatian dari masyarakat dan penegak hukum. Rumusan secara

\footnotetext{
${ }^{13}$ Eti Nurhayati, Psikologi Perempuan dalam Berbagai Perspektif, (Yogyakarta: Pustaka Pelajar, 2012), h. 112-114.

${ }^{14} \mathrm{Ibid}, \mathrm{h} .233-236$.

${ }^{15}$ Adil Samadani, Kompeten si Pengadilan Agama terhadap Tindak Kekerasan dalam Rumah tangga, (Yogyakarta: Graha Ilmu, 2013), h. 29.
} 
yuridis formal memang belum ada dalam KUHP (Kitab undang-undang hukum pidana), tetapi rancangan undang-undang telah diusulkan oleh sejumlah lembaga swadaya masyarakat. Dalam usulan itu, pengertian kekerasan dalam rumah tangga adalah:

"semua perbuatan yang dilakukan seseorang atau beberapa orang terhadap orang lain, yang berakibat atau mungkin berakibat kesengsaraan atau penderitaan secara fisik, seksual, dan atau psikologis, termasuk ancaman, perbuatan tertentu, pemaksaan atau perampasan kemerdekaan secara sewenang-wenang atau penekanan secara ekonomis yang terjadi dalam lingkup rumah tangga" ${ }^{16}$

Fenomena kekerasan rumah tangga memunculkan sejumlah masalah psikologis antara lain: Pertama, bagi pelaku umumnya kaum laki-laki (ayah atau suami), umumnya merasa tidak masalah kekerasan karena dianggap sebagai penerapan power dan wibawa dalam predikatnya sebagai kepala keluarga. Hal ini merupakan kepribadian yang tidak sehat dan cacat secara psikologis, di mana menyengsarakan orang lain apalagi anggotanya sendiri yang patut dilindungi keamanannya, justru dibikin sengsara, sakit, dan menderita, entah secara fisik atau secara psikologis, secara sengaja atau tidak, bertujuan atau tidak, berkepanjangan secara terus menerus atau sewaktuwaktu meluapkan emosi. Orang yang tidak dapat mengendalikan emosi indikasi kepribadian yang belum matang, bukan sekedar tidak cerdas secara emosi tapi juga tidak cerdas secara intelektual. Pelaku kekerasan tidak menggunakan otak kiri dan otak kanan nya untuk mengontrol perilakunya. Apapun dalilnya, melakukan kesalahan tetapi merasa benar atau membenarkan prilaku yang salah merupakan prilaku mal-adjusted (dzalim).17

Kedua, bagi korban ( umumnya ibu atau isteri), umumnya merasa bersalah atau dipersalahkan karena telah menyulut emosi laki-laki untuk melakukan kekerasan, dan diperparah lagi selain mereka telah sakit dan menderita karena mengalami kekerasan, tidak dapat melawan ataupun tidak diperbolehkan melawan, dan disalahkan jika melaporkan peristiwa kekerasan yang dialaminya keluar, apalagi meminta bantuan pihak luar. Dari fenomena kekerasan ini melahirkan kekerasan (kognisi) dan kepribadian yang mal-adjusted. Pelaku yang seharusnya merasa bersalah atau

${ }^{16}$ Sri Suhandjati, Islam Menentang Kekerasan terhadap Istri, h. 7.

${ }^{17}$ Eti Nurhayati, Psikologi Perempuan dalam Berbagai Perspektif, h. 232. 
dipersalahkan, bahkan mengaku benar dan dibenarkan oleh kultur, apalagi dengan mencari pembenaran agama, sementara korban kekerasan yang seharusnya dibela justru mereka merasa bersalah dan dipersalahkan oleh kultur masyarakat di mana mereka tinggal. Padahal penderitaan korban secara fisik maupun psikis mungkin permanen dan menimbulkan luka psikis yang traumatik. ${ }^{18}$

Ketiga, bagi anak-anak yang ikut menyaksikan apalagi ikut menjadi korban kekerasan, mereka akan belajar melakukan kekerasan seperti yang dilakukan ayah mereka, dan bagi anak perempuan akan belajar menghindar bergaul dengan laki-laki, dan bentuk ketakutan traumatis lainnya. Dengan demikian, peristiwa kekerasan dalam rumah tangga, bagi pelaku, korban, maupun anak-anak menyisakan sejumlah problem psikologis yang berkepanjangan. ${ }^{19}$

\section{Faktor-faktor Penyebab KDRT}

Beberapa alasan kecenderungan orang melakukan kekerasan dalam rumah tangga antara lain: Pertama budaya patriarki yang menempatkan posisi pihak yang memiliki kekuasaan merasa lebih unggul. Hal ini laki-laki dianggap lebih unggul dari pada perempuan dan berlaku tanpa perubahan, dan bersifat kodrati. Kedua pandangan dan pelabelan negatif (stereotype) yang merugikan, misalnya laki-laki kasar, sedangkan perempuan lemah, dan mudah menyerah jika mendapatkan perlakuan kasar. Ketiga interpretasi agama yang tidak sesuai dengan nilai-nilai universal agama. Agama sering digunakan sebagai legitimasi pelaku kekerasan terutama dalam lingkup keluarga, padahal agama menjamin hak-hak dasar seseorang, seperti memahami nusyuz, yakni suami boleh memukul istri dengan alasan mendidik atau ketika istri tidak mau melayani kebutuhan seksual suami maka suami berhak memukul dan ancaman bagi istri adalah laknat. Keempat kekerasan berlangsung justru mendapatkan legitimasi masyarakat dan menjadi bagian dari budaya, keluarga, negara, dan praktek di masyarakat, sehingga menjadi bagian kehidupan yang sulit dihapuskan, kendatipun terbukti merugikan semua pihak. Kelima antara suami dan istri tidak saling memahami, dan tidak saling mengerti. Sehingga jika terjadi

${ }^{18}$ Ibid.

${ }^{19}$ Ibid, h. 232-233. 
permasalahan keluarga, komunikasi tidak berjalan baik sebagaimana mestinya. ${ }^{20}$

Galtung menyatakan, "kekerasan terjadi saat ada penyalahgunaan sumber daya, wawasan, dan hasil kemajuan untuk tujuan yang lain dimonopoli oleh komunitas tertentu" komunitas yang dimaksud adalah kaum laki-laki, dimana "mereka memiliki akses terhadap dunia publik yang menjadi berkuasa atas kelangsungan jenis kelamin lain, seolah-olah mengetahui apa yang terbaik bagi perempuan, kemudian menyamakan untuk tidak menyatakan menghiraukan kepentingan kebutuhan perempuan dengan kepentingan laki-laki yang memiliki perbedaan". Hubungan keluarga yang dominan perempuan atau dominan laki-laki, kemungkinan tinggi terjadi kekerasan. ${ }^{21}$

\section{Kekerasan terhadap Perempuan}

Kekerasan terhadap perempuan merupakan perbuatan melanggar hukum dan HAM. Hal tersebut menjadi suatu fenomena faktual dalam kehidupan masyarakat, adapun korban yang cukup menonjol berdasarkan data Komnas Perempuan adalah kekerasan terhadap istri (KDRT) yang setiap tahunnya mengalami peningkatan, dan berimplikasi pada proses perceraian dengan cara khulu' yang lebih dominan daripada talak, karena disebabkan kekerasan terhadap istri, walaupun kekerasan tersebut dilakukan dalam rangka mempertahankan keluarga dari kerusakan. Oleh sebab kekerasan tersebutlah telah menjadikan kondisi psikologis perempuan terganggu, maka proses khulu' pun terjadi dalam hal ini masuk pada ranah KDRT, dan berkaitan erat dengan hak asasi manusia. ${ }^{22}$

Kekerasan terhadap perempuan termasuk masalah pelanggaran HAM yang mendapat perhatian masyarakat di tingkat internasional. Hal ini disebabkan tindak kekerasan terhadap perempuan yang terjadi di berbagai penjuru dunia sampai sekarang belum dapat dibatasi, bahkan cenderung mengalami peningkatan.

${ }^{20}$ Mufidah, Psikologi Keluarga Islam Berwawasan Gender, h. 273-274.

${ }^{21}$ Eti Nurhayati, Psikologi Perempuan dalam Berbagai Perspektif, h. 242-243.

${ }^{22}$ Aji Nugroho, "Pemikiran Agama dan Pemberdayaan: Perempuan dan Kekerasan Mencari Surga di bawah Tangan Suami". Jurnal Dimas. Vol.13 No. 1 Tahun 2013, hlm.1 
Persepsi tentang tindakan kekerasan terhadap perempuan itu akan menentukan batasan tentang tindak kekerasan itu sendiri. Oleh karenanya perlu diketahui rumusan konsep yang dijadikan rujukan untuk memahami kekerasan terhadap perempuan. Ada kelompok masyarakat yang memandang kekerasan yang terjadi di dalam rumah tangga tidak termasuk dalam tindakan kekerasan yang perlu diberi sanksi hukum karena pelaku dan korban terikat dalam lingkup keluarga. Oleh karena itu hal ini sering dianggap persoalan keluarga/ privacy yang tidak dapat dicampuri pihak luar. Namun, disisi lain, karena kekerasan dalam rumah tangga dianggap kekerasan dalam rumah tangga termasuk pelanggaran Hak Asasi Manusia yang menyengsarakan korban, maka termasuk pelanggaran yang harus mendapat sanksi hukum dan dapat diancam pidana. ${ }^{23}$ Secara umum, pengertian kekerasan terhadap perempuan seperti rumusan PBB tahun 1993 tentang Deklarasi Penghapusan Kekerasan Terhadap Perempuan, Pasal 1:

"setiap tindakan berdasarkan perbedaan jenis kelamin (gender-based violence) yang berakibat atau mungkin berakibat kesengsaraan atau penderitaan perempuan secara fisik, seksual, atau psikologis, termasuk ancaman tindakan tertentu, pemaksaan, atau perampasan kemerdekaan secara sewenang-wenang, baik yang terjadi di depan umum maupun kedalam kehidupan pribadi".

Ruang lingkup terjadinya kekerasan terhadap perempuan meliputi kekerasan meliputi kekerasan dalam rumah tangga/domestik (KDRT), kekerasan di masyarakat (publik), dan kekerasan di wilayah negara. Hal ini tercermin dalam Deklarasi PBB tentang Penghapusan Kekerasan Terhadap Perempuan, Pasal 2:

"kekerasan terhadap perempuan harus dipahami mencakup, tetapi tidak hanya terbatas pada: tindak kekerasan secara fisik, seksual, dan psikologis yang terjadi di dalam dan di masyarakat termasuk pemukulan, penyalahgunaan seksual atas perempuan/kanak-kanak, kekerasan yang berhubungan dengan mas kawin, pemerkosaan dalam perkawinan (marital rape), perusakan alat kelamin perempuan dan praktik-praktik kekejaman tradisional lain terhadap perempuan, kekerasan diluar hubungan suami istri, dan kekerasan yang berhubungan dengan eksploitasi perempuan, perkosaan, penyalah-

${ }^{23}$ Sri Suhandjati, Islam Menentang Kekerasan terhadap Istri, h. 2-3. 
gunaan seksual, pelecehan, dan ancaman seksual di tempat kerja, dalam lembaga-lembaga pendidikan, dan sebagainya, perdagangan perempuan dan pelacuran paksa, serta kekerasan yang dilakukan dan dibenarkan oleh negara di mana pun terjadinya". ${ }^{24}$

Lingkup terjadinya kekerasan terhadap perempuan dapat dikelompokkan dalam tiga golongan, yakni:

a. Kekerasan dalam wilayah domestik, meliputi kekerasan yang pelaku dan korbannya terikat berhubungan keluarga atau kedekatan karena faktor lain. seperti penganiayaan terhadap istri, mantan istri, pacar/ tunangan, anak kandung/anak tiri, dan orang tua.

b. Kekerasan dalam wilayah publik yang terjadi di luar hubungan keluarga, seperti ditempat kerja termasuk didalamnya kerja rumah tangga, seperti pembantu rumah tangga baby sitter, perawat lansiaorang sakit juga di tempat umum (di kendaraan umum, pasar, restoran, dll.). kekerasan di wilayah publik adalah pornografi, perdagangan perempuan, pelacuran paksa, dll.

c. Kekerasan yang dilakukan oleh negara atau individu kelompok yang mewakili negara seperti pejabat, polisi/militer. Termasuk dalam kekerasan lingkup negara ini adalah kekerasan yang dibenarkan atau dibiarkan oleh negara, seperti perkosaan, pembunuhan, atau penganiayaan dalam situasi konflik bersenjata. ${ }^{25}$

Kekerasan terhadap istri yang terjadi dalam lingkup rumah tangga pada umumnya sulit diketahui pihak luar. Hal ini disebabkan beberapa hal, antara lain istri yang mengalami kekerasan dari suaminya lebih banyak menyimpan rapat-rapat kasus tersebut karena malu terhadap tetangga atau keluarga. Sebab, tidak jarang justru istri yang dituduh sebagai penyebab timbulnya kekerasan. Di samping itu, korban ada yang merasa takut akan terjadi kekerasan yang berkepanjangan jika ia berani melaporkan atau meminta bantuan kepada pihak lain. maka, sebagian besar menerima tindak kekerasan itu dengan kepasrahan atas nasib yang menimpanya. Dari pihak luar keluarga, kebanyakan tidak mau ikut campur urusan suami istri jika tidak diminta oleh korban. Karena hal itu sudah berada dalam lingkup rumah tangga yang sensitif terhadap campur tangan dari luar.

\footnotetext{
${ }^{24} \mathrm{Ibid}$.

${ }^{25} \mathrm{Ibid} .$, h. 4.
} 
Pada umumnya, kekerasan terhadap perempuan memiliki dampak jangka pendek (short term effect) atau jangka panjang (long term effect). Dampak jangka pendek merupakan akibat spontan dari kekerasan yang mengenai fisik korban, seperti luka-luka pada bagian tubuh akibat perlawanan atau penganiayaan fisik. Adapun akibat psikis misalnya marah, merasa bersalah, malu, dan merasa terhina. Dampak tersebut dapat menyebabkan terjadinya insomnia (kesulitan tidur) ataupun lost appetite (kehilangan nafsu makan). Dampak jangka panjang ini akan berkelanjutan jika ia tidak mendapat bantuan penanganan serius untuk meringankan penderitaannya. Adapun dampak jangka panjang dapat berupa sikap atau persepsi negatif terhadap laki-laki atau seks.

Kekerasan suami terhadap istri pada umumnya memiliki akibat yang berkepanjangan dan sering terjadi secara berulang-ulang karena istri berusaha memendam perasaan untuk mempertahankan keutuhan rumah tangga. pada umumnya, istri tidak suka dengan status janda cerai karena memiliki dampak sosial yang tidak menyenangkan. Karenanya, lebih banyak yang tetap bertahan dalam ikatan perkawinan, walaupun hidup dalam kekerasan. Adanya pergolakan batin antara penderitaan dengan keinginan untuk mempertahankan rumah tangga itu menyebabkan timbulnya perasaan rendah diri dan tidak percaya diri selalu menyalahkan diri sendiri, mengalami gangguan fertilitas (kesuburan) seta gangguan siklus haid karena jiwanya tertekan. ${ }^{26}$

\section{Penanganan Kekerasan terhadap Perempuan di LRC KJHAM}

Sejarah LRC KJHAM (Legal Resource Center untuk Keadilan Jender dan Hak Asasi Manusia) berawal dari pembentukan kelompok kerja dengan fokus untuk pembelaan hak-hak perempuan di wilayah Jawa Tengah. Pembentukan kelompok kerja ini diinisiasi oleh LBH (Lembaga Bantuan Hukum) Semarang - Yayasan LBH Indonesia yang kemudian dikenal dengan nama Kelompok Kerja untuk Keadilan Jender dan Hak Asasi Manusia atau K3JHAM pada tanggal 24 Juli 1999. Pada periode ini program-program K3JHAM memperoleh dukungan pendanaan dari Novib melalui YLBHI (Yayasan Lembaga Bantuan Hukum Indonesia. Selanjut-

${ }^{26}$ Ibid, h. 9-13. 
nya K3JHAM mulai dikenal luas ketika merintis dan melaksanakan kegiatan 'Kampanye 16 Hari Anti Kekerasan Terhadap Perempuan' pada tanggal 25 November - 10 Desember 2000.

Program ini kemudian diadopsi ditingkat nasional dan dikoordinasi oleh Komnas Perempuan. K3JHAM juga menjadi salah satu inisiatif penyusunan laporan bayangan atau laporan independent dari NGO (Non Government Organization) untuk merespon laporan Pemerintah Indonesia kepada Komite CEDAW (Convention on the Elimination of All Forms of Discrimination Against Women's) PBB. K3JHAM bekerja secara efektif dalam melakukan pembelaan hak-hak perempuan di ruang pengadilan maupun di arena kebijakan publik, serta pengembangan konseling untuk perempuan korban tindak kekerasan. K3JHAM juga melaksanakan tanggung jawabnya untuk memperkuat cara kerja bantuan hukum struktural (BHS) bagi kantorkantor LBH-YLBHI dalam aspek keadilan jender dan responsif pada hakhak perempuan miskin.

Pada 2002, YLBHI menilai baik atas kerja K3JHAM dan sebagai kelompok kerja dinyatakan selesai. Namun LBH Semarang memandang penting kerja hak asasi perempuan K3JHAM maka kemudian dibentuklah kelembagaan baru yakni, LRC-KJHAM di bawah Yayasan Sekretariat untuk Keadilan Jender dan HAM (Yayasan Sukma). LRC-KJHAM telah berhasil memprakarsai Pusat Pelayanan Terpadu (PPT) bagi Perempuan dan Anak Korban Kekerasan Propinsi Jawa Tengah tahun 2002. Model PPT dikampanyekan sebagai salah satu mekanisme penanganan pelanggaran hak asasi perempuan dan anak bersama Pemerintah Propinsi Jawa Tengah. Kini, 35 kabupaten/kota di Jawa Tengah telah memiliki PPT. Dengan dukungan dana dari Hivos-Uni Eropa, model PPT diperkuat jangkauan operasionalnya hingga di tingkat kecamatan-kecamatan.

Pada tahun 2009, Raperda (Rancangan Peraturan Daerah) Penyelenggaraan Perlindungan Perempuan dan Anak Korban Kekerasan yang diinisiasi LRC-KJHAM berhasil di ditetapkan Pemerintah Propinsi Jawa Tengah dengan Perda No. 3 tahun 2009. Keberadaan Perda tersebut diharapkan dapat memperkuat komitmen dan kemampuan pemerintah provinsi dan kabupaten /kota di Jawa Tengah dalam merealisasikan hakhak asasi perempuan sebagai hak asasi manusia. Dan pada tahun 2011, giliran Pemerintah Kota Semarang menyusun Raperda Perlindungan 
Perempuan dan Anak Korban Kekerasan. Pada Tahun 2010 atas dukungan Yayasan TIFA, WRIA dan FPAR (Forum Peduli Aspirasi Rakyat) telah dikembangkan untuk memperkuat pemenuhan hak atas kesehatan kelompok perempuan miskin, marjinal dan rentan. Dan pada tahun 20112012 atas dukungan dari Hivos FPAR dan WRIA dikembangkan lagi untuk meningkatkan komitmen dan kebijakan pemerintah lokal terhadap pelayanan terpadu bagi perempuan dan anak korban kekerasan. FPAR dan WRIA akhirnya menjadi alat yang efektif untuk memperluas partisipasi perempuan dan untuk mendorong perbaikan kebijakan. ${ }^{27}$

\section{Program Kerja}

Untuk mencapai isu strategis yang selaras dengan cita-cita kelembagaan maka dalam hal ini LRC-KJHAM melakukan kegiatan-kegiatan sebagai berikut:

a. Pendampingan korban-korban kasus kekerasan berbasis gender di Jawa Tengah dengan bantuan hukum dan layanan konseling.

b. Memfasilitasi penanganan kasus-kasus berbasis gender dengan membentuk jaringan kerja penanganan kasus.

c. Melakukan kampanye tentang advokasi kebijakan alternatif yang berperspektif gender dengan pelatihan jurnalisme gender, pelatihan penegakan hukum berperspektif gender, studi kebijakan tentang penerapan-penerapan konvensi-konvensi internasional yang terkait dengan penegakan hak-hak perempuan sebagai hak azasi manusia. Disamping itu, juga mengadakan seminar hasil studi kebijakan, publikasi hasil studi dan kebijakan, diskusi panel I dan II untuk sosialisasi advokasi kebijakan alternatif.

d. Menyediakan informasi dan dokumentasi kasus dan media kampanye dengan pengadaan referensi dan media kampanye.

e. Memfasilitasi pendidikan kritis untuk masyarakat korban dengan pengorganisasian buruh perempuan, buruh perempuan pabrik di Semarang, Ungaran, dan Solo, buruh tani/perkebunan di wilayah Kendal (Arsip buku panduan LRC-KJHAM Semarang).

${ }^{27}$ www.lrc-kjham.com/sejarah/02.1511 Mei 2012. 


\section{Mekanisme Layanan bagi Perempuan Korban KDRT di LRC- KJHAM}

Penanganan kasus kekerasan KDRT terhadap perempuan di LRCKJHAM Semarang tidak jauh berbeda dengan penanganan terhadap kasus yang lain, seperti: kekerasan seksual, trafficking, dan yang lainnya. Cara yang digunakan yaitu dengan menggunakan sistem PAR (Participation Action Research). Sistem PAR ini merupakan cara penanganan tindak kekerasan berbasis gender dengan melibatkan langsung korban sebagai subyeknya, sehingga istilah klien lebih tepat menggunakan istilah mitra. Artinya hubungan antara konselor (pendamping korban dari LSM) dengan korban bukan secara vertikal, melainkan secara horisontal. Keduanya saling membantu dalam menyelesaikan kasus kekerasan yang sedang dihadapi. Dalam penanganan kasus, apapun yang akan dilakukan terhadap kasus tersebut adalah keputusan korban sendiri. selanjutnya, pihak pendamping hanya bertugas memberitahukan kepada korban tentang resiko apa yang mungkin akan terjadi apabila sebuah keputusan dilakukan.

Prosedurnya korban datang sendiri atau menghubungi lewat telpon. Kemudian korban mengisi identitas dan jenis kasus yang akan diajukan kepada pihak LSM. Setelah pemaparan kasus jelas, pihak LRCKJHAM akan memutuskan apakah kasus tersebut layak untuk didampingi atau tidak. Sesuai dengan prinsip yang ditetapkan oleh LRC-KJHAM, bahwa standar kasus untuk bisa memperoleh pendampingan hukum harus memuat beberapa faktor yaitu:

a. Kasus tersebut termasuk kasus Kekerasan Berbasis Gender (KBG), yaitu mengacu pada Deklarasi CEDAW dan Rekomendasi No.19 PBB.

b. Sesuai dengan kapasitas yang dimiliki oleh lembaga LRC-KJHAM. Dalam hal ini, harus sesuai dengan kapasitas teritorial LRC-KJHAM yaitu khusus untuk daerah di Jawa Tengah dan juga kapasitas SDM (Sumber Daya Manusia).

c. Mitra kasusnya bersedia untuk dipublikasikan dalam rangka penguatan hak-hak perempuan khususnya perempuan korban.

d. Berperan aktif dalam setiap proses penanganan kasusnya.

e. Mitra bersedia terlibat aktif dalam perjuangan hak-hak perempuan di Indonesia, khususnya di Jawa Tengah. 
f. Kasus tersebut sangat strategis, artinya pelakunya adalah pejabat publik, bentuk kejahatannya tergolong berat, modus kejahatannya baru dan belum ada ketentuan hukum tentang kasus tersebut. ${ }^{28}$

Dari semua persyaratan di atas, unsur yang wajib untuk dipenuhi adalah unsur ke satu dan ke dua. Apabila kedua unsur ini terpenuhi, maka kasus tersebut akan langsung diterima dan selanjutnya akan ditindak lanjuti. Sebaliknya, jika kedua unsur tersebut tidak terpenuhi maka korban boleh memilih apakah kasusnya akan dibawa ke pengacara biasa atau akan menyelesaikannya sendiri. Kasusnya akan di proses secara otomatis jika disetujui oleh pihak lembaga LRC-KJHAM dan selanjutnya akan melakukan pendampingan sesuai dengan kapasitas yang dimiliki. Adapun bentuk pendampingan hukum yang biasa dilakukan oleh LRC-KJHAM dalam menangani kasus kekerasan berbasis gender adalah sebagai berikut:

\section{a. Konseling}

Penanganan kasus melalui konseling ini dilakukan dengan cara mendata dulu kasus yang diajukan. Layanan yang akan di dapatkan oleh korban sesuai dengan bentuk kasus yang dihadapinya. Hampir semua korban sebagaimana korban kekerasan sangat dihantui dengan suatu sikap dan perasaan yang tidak menentu atau mudah frustasi, dalam kondisi yang demikian, kehadiran seorang konselor atau pendamping terhadap psikologi korban sangatlah diperlukan. Tujuan diadakannya konseling ini tidak hanya semata-mata untuk proses terapi sementara, melainkan sebagai terapi yang berkelanjutan sampai dengan target yang tertinggi untuk menyadarkan korban dalam kondisi kesadaran yang kritis. Keberhasilan dalam tahap konseling ini sangat berpengaruh terhadap kesiapan korban dalam menghadapi proses peradilan hukum. Apabila korban belum siap menghadapi jalur hukum, maka akan berakibat buruk terhadap psikologi korban dan akhirnya proses hukum akan menjadi terhambat. Hal inilah mengapa sangat penting sekali dalam memberikan konseling terlebih dahulu terhadap korban sebelum kasusnya diselesaikan melalui jalur hukum..$^{29}$

${ }^{28}$ Dokumentasi Bidang Internal LRC-KJHAM Semarang pada tanggal 27 juni 2014

${ }^{29}$ Wawancara dengan Helen Intania (Kabid Internal), 27 Juni 2014. 


\section{b. Monitoring}

Monitoring dilakukan untuk mengetahui perkembangan kasus yang didata oleh pihak konselor. Selain itu, untuk mengetahui perkembangan yang dialami oleh korban selama proses pendampingan. Kegiatan yang dilalui dalam proses monitoring adalah dengan mendokumentasikan data awal kasus dalam bentuk kronologis kasus. Langkah selanjutnya baru mendokumentasikan data dalam bentuk perkembangan kasus. Pada fase monitoring perkembangan kasus, biasanya didapatkan kecenderungan psikologis dari masing-masing korban (klien). Sehingga catatan ini sangat penting untuk menentukan langkah selanjutnya yang akan diambil. Dan tidak jarang pula dalam kondisi semacam ini, korban mengalami pasang surut emosional)..$^{30}$

\section{c. Bantuan Hukum}

Masalah bantuan hukum terhadap korban kekerasan dalam rumah tangga ini diberikan apabila dari pihak korban menginginkan kasus mereka akan diselesaikan melalui jalur hukum. Pelaksanaan penanganan kasus yang didampinginya, LRC-KJHAM menggunakan dua macam sistem atau bentuk bantuan hukum, yaitu dengan cara konsultasi hukum dan sebagai kuasa hukum. Kedua bentuk tersebut disesuaikan berdasarkan jenis kasus dan kondisi mitra.

Kasus-kasus pidana seperti kekerasan, pihak mitra memperoleh pendampingan berupa kuasa hukum yang berfungsi sebagai konsultan. Disamping itu, memberitahu korban tentang materi hukum sesuai dengan kasus yang dialaminya serta memperhitungkan resiko yang mungkin terjadi untuk dicari alternatif lain karena dalam proses hukum korban diwakili oleh pihak jaksa. Apabila diperlukan dalam proses bantuan hukumnya, pihak LRC-KJHAM bisa melakukan aksinya dengan cara meminta dukungan ke LSM lain, lobi dengan pihak pengadilan ataupun demonstrasi. Cara lobi ini dilakukan agar tidak terjadi kesalahpahaman dengan pihak kejaksaan ataupun pihak keadilan terhadap kasus yang ditanganinya. ${ }^{31}$

${ }^{30}$ Wawancara dengan Helen Intania (Kabid Internal), 27 Juni 2014.

${ }^{31}$ Wawancara dengan Helen Intania (Kabid Internal), 27 Juni 2014 


\section{Proses Bimbingan Konseling bagi Perempuan Korban KDRT di LRC-KJHAM}

Nurhayati menjelaskan bahwa peran konselor adalah menyadarkan korban atas kekerasan yang telah dialami dan kekerasan tersebut tidak boleh dibiarkan begitu saja. bantuan yang diberikan kepada korban tidak terbatas hanya pada bantuan dari segi fisik semata, akan tetapi harus pula mempertimbangkan dampak mental dan psikis yang diderita korban. Korban juga membutuhkan bantuan ekstra dari sisi psikologis, mental, spiritual, dari psikolog maupun konselor. ${ }^{32}$

Peran utama konselor dalam konseling dengan menggunakan landasan normatif agama adalah sebagai pengingat, yaitu sebagai orang yang mengingatkan individu yang dibimbing dengan cara Islam. Mengingat esensi konseling dengan pendekatan ini adalah upaya membantu individu belajar mengembangkan fitrah apa yang sudah tuhan berikan dan kembali kepada fitrahnya sebagai manusia. Dari sini tampak bahwa peran konselor tidak lebih sebagai pendamping, orang yang didampingi tentu dekat dengan yang didampingi, dan pendamping duduk dan berdiri setara dengan yang didampingi. ${ }^{33}$

Ada dua tahapan konseling yang harus dilalui perempuan korban kekerasan dalam rumah tangga di LRC-KJHAM Semarang yaitu konseling individu dan kelompok. Konseling individu diberikan oleh konselor kepada korban melalui beberapa langkah. Pertama yang harus dilakukan adalah konselor sebagai pendamping harus berusaha membangun hubungan baik dengan korban supaya korban dapat terbuka terhadap semua permasalahannya. Kedua, berusaha mengklarifikasi masalah korban dengan pertanyaanpertanyaan sehingga pembahasan lebih fokus. Ketiga, selanjutnya konselor berusaha mencari titik temu permasalahan dan menentukan keputusan apa yang akan diambil oleh korban. Dari semua proses yang dilalui saat konseling tujuan yang diharapkan yaitu: pertama, korban bisa sadar apa yang telah dialami bahwa tidak dibenarkan. Kedua, pemberian informasi apa saja hak-hak korban yang bisa di dapatkan. Ketiga, korban dapat

\footnotetext{
32Eti Nurhayati, Psikologi Perempuan dalam Berbagai Perspektif, h. 155.

${ }^{33}$ Wawancara dengan Dian Puspitasari (Divisi Bantuan Hukum dan Konseling), 21 Mei 2015.
} 
menentukan langkah apa yang akan di ambil dengan paham resikonya agar tidak ada penyesalan. ${ }^{34}$

Penanganan masalah dengan menggunakan landasan agama juga dilalui saat itu, konselor juga tidak lupa mengingatkan agar selalu sabar dan lebih mengingat tuhan serta menjalankan kewajiban sesuai perintah agama yang saya anut. Menurutnya bimbingan konseling berbasis agama/Islam sangat perlu karena ibu $\mathrm{M}$ beranggapan dalam Al-Qur'an telah dijelaskan dalam surat an-Nisa ayat 148 bahwa Allah tidak suka yang menceritakan keburukan orang kecuali yang di dizalimi. Perlunya bagaimana kita bisa menjaga iman karena sesulit apapun permasalahan yang dialami jika iman sudah kuat perasaan putus asa akan bisa diminimalisir.LRC-KJHAM menjelaskan apa saja yang bisa mereka bantu baik dari proses penanganan hukum dan penanganan secara psikologis. Pelayanan konseling di LRCKJHAM sangat membantu bagi korban KDRT yang bisa dikatakan sudah masuk fase hopeless. Karena selain konseling individu ada juga support group sebagai media konseling kelompok bagi sesama korban KDRT untuk saling menguatkan bahwa mereka tidak sendiri. Selain proses konseling individu, konselor mempersilahkan untuk mengikuti support group (konseling kelompok). Melalui support group korban bisa saling menguatkan dengan saling memberi saran, karena support group sendiri tidak hanya diikuti oleh korban yang sedang menghadapi masalah, tetapi mitra yang sudah selesai masalahnya pun disarankan untuk ikut, hal tersebut sangat bermanfaat karena antar personal bisa saling bertukar pengalaman.

Konseling kelompok merupakan kelompok terapi yang masing-masing anggotanya saling berdiskusi atas pengalaman permasalahan yang klien alami dan juga saling memberikan pengertian serta perhatian satu sama lain yang bertujuan untuk menumbuhkan kepercayaan diri anggotanya. Permasalahan yang dikomunikasikan atau didiskusikan menyangkut halhal pribadi, keluarga, rumah tangga, dan isu sosial. Konseling kelompok bertujuan membantu permasalahan, jika klien menginginkan hal tersebut, kemudian akan diarahkan pada proses pemberian bantuan. Konseling kelompok (Support group) di LRC-KJHAM merupakan wadah perempuan korban kekerasan dalam rumah tangga untuk bertemu tiap bulannya, untuk saling berdiskusi, berempati, menolong, serta saling menguatkan kondisi Mei 2015.

${ }^{34}$ Wawancara dengan Dian Puspitasari (Divisi Bantuan Hukum dan Konseling), 21 
setiap anggotanya. Konseling kelompok memiliki tujuan untuk mengembangkan pikiran, pemahaman dan keterampilan agar dapat menjadi sarana pemecahan masalah. Melalui konseling kelompok diharapkan para individu korban mampu menyadari bahwa ia tidak sendiri dan mereka secara bersama dapat berjuang untuk mengatasi masalah yang mereka alami). ${ }^{35}$ Struktur/komponen dalam support group di LRC-KJHAM Semarang meliputi.

a. Pemimpin kelompok. Tugas pemimpin kelompok secara umum adalah mempertahankan kelompok, membentuk budaya dalam kelompok, dan membentuk norma-norma dalam kelompok. Secara khusus pemimpin kelompok diwajibkan menghidupkan dinamika kelompok di antara semua anggota seintensif mungkin yang mengarah kepada pencapaian tujuan umum dan khusus.

b. Anggota kelompok (survivor). Para anggota kelompok dapat beraktivitas langsung dan mandiri dalam bentuk berfikir, berpendapat, berempati dan bersikap. Setiap anggota kelompok dapat menumbuhkan kebersamaan yang diwujudkan dalam sikap antara lain: pembinaan keakraban dan keterlibatan emosional, kepatuhan terhadap aturan kelompok, saling memahami, memberi kesempatan dan membantu, dan menyukseskan kegiatan kelompok.

c. Agenda kelompok:

1) Konseling, diharapkan dapat mengembangkan pribadi, membahas dan memecahkan masalah pribadi melalui dinamika kelompok yang dialami oleh masing-masing anggota.

2) Pemberdayaan, yang dilaksanakan support group mencakup pemberian keterampilan berbicara, membuat kerajinan, dan berorganisasi.

3) Pendidikan dan kampanye. Pemberian pemahaman masalah gender dan ikut berperan aktif dalam menyerukan masalah dan isu-isu diskriminasi terutama pada kelompok perempuan miskin, marjinal, dan rentan tindak kekerasan.

4) Rapat dan evaluasi. Rapat dan evaluasi dilaksanakan kelompok pada tahap awal dan akhir yang telah ditetapkan. ${ }^{36}$

${ }^{35}$ Wawancara dengan klien 22 September 2015.

${ }^{36}$ Wawancara dengan klien 22 September 2015 
Tahapan kegiatan konseling kelompok terdiri dari beberapa tahap yang diantaranya adalah sebagai berikut:

a. Tahap pembentukan. Merupakan tahap pengenalan dan pelibatan diri atau tahap memasukkan diri kedalam kehidupan ke sebuah kelompok. Anggota saling mengenalkan dan mengungkapkan tujuan ataupun harapan yang ingin dicapai.

b. Tahap peralihan. Pemimpin kelompok akan menjelaskan apa saja agenda yang akan dilakukan. Pemimpin kelompok akan menjelaskan apa saja peranan anggota kelompok.

c. Tahap kegiatan. Tahap ini adalah inti tahap mengentaskan masalah pribadi anggota kelompok. Kegiatan meliputi setiap kelompok mengemukakan masalah pribadi yang perlu mendapatkan bantuan untuk pengentasannya dengan menjelaskan lebih rinci masalah yang dialami, kemudian anggota lain merespon apa yang telah disampaikan.

d. Tahap akhir. Pada tahap ini dimana semua kegiatan akan diakhiri, namun tidak dalam artian berakhir begitu saja. Masih ada kegiatan selanjutnya yang bisa dilakukan yang diantaranya:

1) Frekuensi pertemuan. Berkaitan dengan frekuensi pertemuan yang akan dilakukan selanjutnya

2) Pembahasan keberhasilan kelompok. Kegiatan dipusatkan pada pembahasan dan penerapan hal-hal yang telah anggota dapatkan dan pelajari dengan tujuan agar diterapkan dalam kehidupan sehari-hari.

Konseling kelompok meskipun sangat membantu pemulihan psikologis korban juga dibutuhkan dukungan lain. seperti dukungan finansial selama menjalani support group atau dipermudahkan ijin bagi yang kerja. Dalam persoalan kekerasan dalam rumah tangga juga harus dipahami jika korban juga membutuhkan penguatan ekonomi untuk survive. Selama ini yang sering terjadi korban tidak aktif karena harus mencari nafkah untuk keberlanjutan hidupnya, karena support group selama ini fokus memfasilitasi bagi korban perempuan miskin rentan dan marjinal. ${ }^{37}$

${ }^{37}$ Wawancara dengan Dian Puspitasi 29 september 2015 


\section{E. Analisis Pelaksanaan Bimbingan Konseling terhadap Perempuan Korban KDRT di LRC-LKJHAM Semarang}

Penanganan melalui konseling merupakan salah satu cara yang dilalui LRC-KJHAM yang berkomitmen menangani korban kasus kekerasan dalam rumah tangga. Konseling berbasis gender diberikan oleh divisi konseling, kegiatan ini merupakan kegiatan konseling kepada korban kekerasan terhadap istri. Adapun penanganan terhadap istri korban kekerasan pada dasarnya mengacu pola pelayanan dan pendekatan dalam menyelesaikan masalah.

\section{Bimbingan Konseling Individual}

Tujuan konseling adalah menghapus kekerasan, membantu korban mengenali prilaku, dan mengenali prilaku yang tidak sesuai (mal-adjusted) untuk pertimbangan bersama, memelihara kualitas adaptif dalam hubungan, dan memusatkan pada aspek interaksi pasangan suami isteri. Ketika situasi kekusutan telah normal kembali, pasangan suami isteri dapat diajak mendiskusikan tanggung jawab bersama, menilai kemampuan pasangan terlibat dalam treatment, mengomunikasikan perasaan mengamati prilaku, dan bekerja ke arah pemecahan masalah.

Dalam menyelidiki permasalahan konselor harus menghindari menyalahkan korban, dan harus menyadari pula bagaimana korban dengan mudah dipermasalahkan oleh pelaku, karena filosofi dan nilai-nilai pribadi konselor sering masuk dalam treatment menjadi bagian dari proses terapi. Konselor harus juga mengenal isu gender, mencakup undang-undang penghapusan kekerasan dalam rumah tangga, tanda klinis korban, mengetahui dimana korban harus meminta bantuan dan perlindungan, dan umumnya bagaimana intervensi ketika seorang klien mengadukan suatu masalah potensi kekerasan dalam rumah tangganya. ${ }^{38} \mathrm{Hal}$ tersebut juga menjadi fokus perhatian konselor di LRC-KJHAM sebagaimana dikatakan Dian Puspitasari, selaku konselor dalam wawancara tanggal 21 Mei 2015:

"Ketika korban memutuskan untuk datang ke LRC-KJHAM, maka hal pertama yang akan dilakukan oleh konselor yaitu membuat rasa

${ }^{38}$ Eti Nurhayati, Psikologi Perempuan dalam Berbagai Perspektif, h. 163. 
nyaman. Dengan cara tidak memaksakan korban untuk menyampaikan yang di alami saat itu juga, selanjutnya konselor akan menyerahkan keputusan kepada korban apakah korban akan mengambil keputusan bercerita secara lisan atau tertulis. Konselor akan menyampaikan apa saja yang menjadi hak-hak korban selama proses konseling, penyampaian informasi mengenai hak korban yaitu bertujuan akan korban bisa membangun kepercayaan dan kenyamanan pada korban bahwa ia merasa akan menceritakan apa yang ia alami kepada orang yang tepat, karena dengan cara tidak memaksa dan menyalahkan korban akan membuat korban nyaman".

Berdasarkan pernyataan diatas dapat dianalisis bahwa konselor perlu menekankan kekuatan hubungan, terutama sekali dalam permulaan langkah konseling. Konselor perlu memonitor emosi korban untuk mencegah amukan emosi yang berlebihan. Membiarkan kekerasan terus berlangsung dan memunculkan kembali sesi konseling tanpa tujuan yang spesifik adalah tidak produktif, terutama dengan pasangan yang sudah menunjukkan kekerasan dalam hubungan mereka. Tujuan penting lain adalah meningkatkan pilihan kesadaran korban, karena sikap pasrah menghadapi adalah tindakan konyol. Tujuan konseling paling utama untuk menetapkan bahwa kekerasan tidak dapat diterima, konselor harus mengetahui bagaimana cara mendengarkan suatu permasalahan dan melihat selain keluhan fisik. konselor membiarkan klien mengungkapkan kebutuhan untuk intervensi psikologis dalam kaitan dengan gejala hubungan yang mengandung kekerasan dan kecemasan. ${ }^{39}$

Proses konseling adalah cara konselor dan korban bekerja sama untuk membantu korban mengembangkan perasaan, sikap dan prilaku yang lebih sehat agar berfungsi untuk memecahkan masalah. Sebagaimana dikatakan Dian Puspitasari selaku konselor dalam wawancara tanggal $21 \mathrm{Mei}$, menyatakan:

"ketika proses konseling dimulai hal yang pertama yang harus dilakukan adalah konselor sebagai pendamping harus berusaha membangun hubungan baik dengan korban supaya korban dapat terbuka terhadap semua permasalahannya. kedua, berusaha meng-

${ }^{39}$ Ibid, h. 164. 
klarifikasi masalah korban dengan pertanyaan-pertanyaan sehingga pembahasan lebih fokus. Ketiga, selanjutnya konselor berusaha mencari titik temu permasalahan dan menentukan keputusan apa yang akan diambil oleh korban. Dari semua proses yang dilalui saat konseling tujuan yang diharapkan yaitu: pertama, korban bisa sadar apa yang telah dialami bahwa tidak dibenarkan. Kedua, pemberian informasi apa saja hak-hak korban yang bisa di dapatkan. Ketiga, korban dapat menentukan langkah apa yang akan di ambil dengan paham resikonya agar tidak ada penyesalan".

Pernyataan tersebut menunjukkan konseling individual terdapat hubungan yang berupa bantuan satu-satu yang berfokus kepada pertumbuhan dan penyesuaian pribadi, dan memenuhi kebutuhan akan penyelesaian problem dan kebutuhan pengambilan keputusan. Bantuan itu merupakan proses berpusat kepada klien yang menuntut kepercayaan diri konselor dan kepercayaan klien padanya. Proses ini dimulai ketika suatu kondisi berupa kontak atau relasi psikologis terbentuk antara konselor dan klien; ia akan bergerak maju ketika kondisi-kondisi tertentu yang esensial bagi kesuksesan proses konseling terpenuhi. Banyak praktisi percaya kondisi-kondisi esensial ini meliputi hal-hal seperti ketulusan dan kongruensi konselor, penghargaan terhadap klien dan sebuah pemahaman empatik atas kerangka acuan internal klien. ${ }^{40}$

Hasil wawancara peneliti terhadap klien di LRC-KJHAM Semarang yang telah melalui proses bimbingan konseling individu oleh LRC-KJHAM sangat terpadu, dimulai dari pertama pengenalan terhadap masalah yang sedang alami. kedua, melakukan penyadaran bahwa yang telah saya alami tidak dibenarkan, ketiga pemberian informasi bahwa apa saja yang dapat di lakukan untuk menyelesaikan masalah. Keempat, pengembangan potensi yang saya miliki agar bisa survive dalam menyelesaikan masalah. Kelima, penentuan keputusan apa yang akan saya ambil dengan mengetahui resiko yang akan terjadi agar tidak ada penyesalan di akhir.

"waktu saya menjalani masa konseling di KJHAM saya perlahan merasa lebih kuat, saya menjadi lebih tau dengan keadaan saya dan apa yang harus saya lakukan, saya juga jadi sedikit paham apa aja

${ }^{40}$ Robert L Gibson, dan Mariane H Mitchell, Bimbingan dan Konseling, (Yogyakarta: Pustaka Pelajar, 2011), h. 50. 
resiko yang bakal saya terima. Itu juga karena acara-acara KJHAM yang saya ikuti seperti diskusi, workshop. jadi dapat lihat dunia luar saya merasa hidup itu ada gunanya, dari tadinya kan merasa woh kok aku menderita koyok ngene. Saya jadi tambah wawasan, tambah ilmu membuat kuat gitu lho mas". ${ }^{41}$

LRC-KJHAM menjelaskan apa saja yang bisa mereka bantu baik dari proses penanganan hukum dan penanganan secara psikologis. Pelayanan konseling di LRC-KJHAM sangat membantu bagi korban KDRT yang bisa dikatakan sudah masuk fase hopeless. Karena selain konseling individu ada juga konseling kelompok bagi sesama korban KDRT untuk saling menguatkan bahwa mereka tidak sendiri.

"Prosesnya dulu waktu saya dikonseling yang saya rasakan pertama, saya diberitahu apa saja kerugian yang telah saya terima karena dijelaskan juga kekerasan tersebut sangat merugikan korban seperti saya. Kedua, adalah pemberian informasi tentang apa saja hak yang harus saya dapatkan sebagai istri. Ketiga, memberdayakan yang sudah dimiliki agar bisa bangkit juga bisa menentukan tindakan apa saja yang diambil dengan terlebih dahulu dikasih tau kemungkinan resiko apa saja yang akan timbul".

Semua proses dan tahapan saling mempengaruhi, karena antara satu dengan yang lain di rasakan saling berkesinambungan.

"waktu itu, hal pertama yang konselor tekankan kepada saya bagaimana saya harus bisa mengembalikan kepercayaan diri saya dulu, karena sangat penting dalam kelanjutan proses konseling selanjutnya, kalo saya percaya diri dengan diri saya sendiri pada kondisi saat itu maka sangat cepat sadar bahwa saya itu mampu ngatasin masalah yang saya hadapi" ${ }^{42}$

Sebagaimana diungkapkan dalam kutipan wawancara diatas peneliti berpendapat proses konseling telah melalui tahapan-tahapan yang perlu dilalui dalam bimbingan konseling, yang diantaranya:(1) membangun hubungan, (2) mengindentifikasi masalah, (3) merencanakan pemecahan masalah, (4) pengaplikasian solusi dan penutupan konseling. ${ }^{43}$

${ }^{41}$ Wawancara dengan Ibu M, 23 Juni 2015.

${ }^{42}$ Wawancara dengan Ibu C, 23 Juni 2015.

${ }^{43}$ Robert L Gibson, dan Mariane HMitchell, Bimbingan dan Konseling, h. 239. 
Peneliti berpendapat adanya kekurangan dalam proses bimbingan konseling bagi korban yang telah disebutkan di bab sebelumnya, dimana tidak adanya konseling yang mempertemukan korban dengan pelaku (suami), hal ini bagi peneliti menjadi penting karena:

a. Pelaku kekerasan adalah orang yang seharusnya bertanggung jawab atas tindak kekerasan yang dilakukannya dan harus disadarkan bahwa tindakannya bukan sekedar kesalahpahaman rumah tangga biasa, melainkan merupakan kejahatan.

b. Tujuan konseling bagi pelaku maupun korban untuk membantu mereka membuat keputusan sendiri, agar klien selanjutnya menjadi mandiri untuk menghentikan kekerasan dan membangun bersama rumah tangga yang harmonis.

Selama konseling berlangsung, konselor mengambil peran bukan sebagai figur otoratif yang selalu mengarahkan klien, tetapi lebih sebagai mitra yang mendengarkan secara aktif keluh kesah klien. Penerimaan secara penuh dari konselor merupakan kunci keberhasilan proses konseling. Sikap penerimaan yang penuh dari konselor ini akan mendorong klien untuk meneliti perasaan-perasaan tidak sadar menjadi sadar. ${ }^{44}$

\section{Bimbingan Konseling Kelompok (Support Group)}

Melalui dinamika interaksi sosial yang terjadi di antara anggota kelompok, masalah yang dialami oleh masing-masing individu dicoba dientaskan. Peranan konselor dalam konseling perorangan diperkuat oleh peranan dinamika interaksi sosial dalam suasana kelompok. Dengan demikian, proses pengentasan masalah individu dalam konseling kelompok mendapatkan dimensi yang lebih luas. Kalau dalam konseling perorangan klien hanya memetik manfaat dari hubungannya dengan konselor saja, dalam konseling kelompok klien memperoleh bahan-bahan bagi pengembangan diri dan pengentasan masalahnya baik dari konselor maupun rekan-rekan anggota kelompok. Sebagaimana yang disampaikan Dian Puspitasari selaku konselor melalui wawancara tanggal 29 september 2015:

"Sebelum korban memutuskan atau mengetahui tindakan yang akan diambil, maka keputusan tersebut adalah keputusan yang diambil

${ }^{44}$ Eti Nurhayati, Psikologi Perempuan dalam Berbagai Perspektif, h. 111-115. 
secara sadar dan penting, kemudian kita diskusikan bersama-sama bagaimana strateginya. Jadi konselor berusaha menjelaskan apa saja resiko, hambatan, dan keuntungan. Yang diharapkan dari proses yang dilalui tersebut, klien mendapatkan pelajaran, minimal dia paham apa yang sudah disampaikan. Selain sadar akan apa yang dia alami dan mengetahui haknya, klien bisa memberikan dukungan kepada perempuan yang mengalami hal yang sama" ${ }^{45}$

Konseling kelompok terfokus pada pembahasan masalah pribadi individu sebagai peserta kegiatan layanan konseling kelompok dalam upaya pemecahan masalah. Tujuan tersebut diantaranya:

a. Dapat berkembangnya perasaan, pikiran, persepsi, wawasan dan sikap terarah kepada tingkah laku, khususnya dalam bersosialisasi atau komunikasi.

b. Dapat memecahkan masalah individu bersangkutan dan diperolehnya jawaban pemecahan masalah tersebut bagi individu-individu lain anggota konseling kelompok (support group) ${ }^{46}$

Konseling kelompok menawarkan sejumlah cara membantu korban yang tidak ditemukan dalam konseling individual. Kelompok menyediakan arena di mana korban dapat menyaksikan cakupan prilaku individual yang lebih jelas dibandingkan dengan yang dapat diobservasi dalam hubungan konseling one-to-one dengan konselor. Dengan demikian konseling kelompok menghadirkan kualitas informasi tentang klien yang berbeda kepada konselor, dan kesempatan berbeda untuk kesegeraan dan penanganan saat itu. Lebih jauh lagi, dalam kelompok terdapat kesempatan bagi korban untuk membantu yang lain melalui klarifikasi, tantangan, dukungan. Hal ini bukan saja bermanfaat karena tindakan tersebut mengandung lebih banyak bantuan, tetapi juga seorang korban yang mampu memberikan bantuan kepada yang lain akan mendapat manfaat dalam arti mendorong kepercayaan dirinya.

Setelah korban selesai memaparkan permasalahan yang menimpanya, kemudian disepakati anggota yang bersedia dipersilahkan untuk memaparkan permasalahan kekerasan yang ia alami. Setelah korban

\footnotetext{
45Wawancara Dian Puspitasari selaku konselor tanggal 29 september 2015.

${ }^{46}$ Prayitno dan Erman Amti, Dasar-dasar Bimbingan dan Konseling, (Jakarta: Rineka Cipta, 2013), h. 311-312.
} 
memaparkan pengalaman kekerasan yang telah ia alami, kemudian konselor mempersilahkan anggota memberikan suaranya mengenai permasalahan yang sudah dipaparkan. Sebagaimana disampaikan ibu $\mathrm{C}$ selaku peserta konseling kelompok melalui wawancara 22 September 2015:

"sesudah konselor ngasih tau agar mitra yang lain untuk menanggapi masalah yang udah disampaikan, kebanyakan mitra yang lain ngasih dukungan moral, ada yang coba ngasih solusi, nasihat, seperti agar selalu sabar, tidak menyalahkan diri sendiri" ${ }^{47}$

Memberi dukungan kepada korban agar tidak merasa putus asa, malu, cemas, merasa sendirian, sekaligus menjadi kawan dalam menghadapi masa-sama sulit agar bisa kembali menemukan kepercayaan dirinya, dan membantu memperoleh pemahaman tentang diri sendiri dan masalahnya dengan membantu untuk memahami kelebihan dan kekurangan diri. Kemudian konselor membantu korban untuk membuat rencana kedepan akan tindakan apa yang perlu diambil untuk menghindari situasi kekerasan yang berlanjut dengan cara memberi informasi tentang hak korban agar mengetahui solusi yang dapat diambil, tidak sekedar diam dan pasrah menerima nasib (ibu C, wawancara 22 september 2015).

Manfaat dari proses konseling kelompok tersebut yaitu dapat membuat korban mengambil tindakan, seperti membuka diri dari saran dan masukan yang diberikan mitra lainnya. Konseling kelompok juga perlahan-lahan membuat mental individu berpikir secara kelompok dan membantu mengatasi problem klien lewat penyesuaian diri. ${ }^{48}$

Ketentuan yang diikuti dalam konseling kelompok ialah ketentuan berkenaan dengan pengembangan suasana interaksi yang akrab, hangat, permisif, terbuka. Masing-masing anggota dalam berbicara dan menanggapi pembicaraan anggota lain harus dengan sopan. Berusaha memahami dan menerima apa adanya pendapat orang lain, mengendalikan diri dan bertenggang rasa. Aturan lain misalnya, berbicara tidak perlu berkeliling bergiliran, dan tidak perlu menunggu ditunjuk oleh konselor: tetapi tetap berbicara satu per satu, tidak berebutan; setiap masalah yang dialami anggota dibicarakan sampai tuntas, masalah mana yang didahulukan

${ }^{47}$ Wawancara dengan Ibu C, 22 September 2015.

${ }^{48}$ Robert L Gibson, dan Mariane HMitchell, Bimbingan dan Konseling, h. 275. 
pembahasannya dan urutan berikutnya ditentukan secara musyawarah. Dengan demikian jelas bahwa konseling kelompok memang memenuhi unsur-unsur kelompok yang paling mendasar. ${ }^{49} \mathrm{Hal}$ tersebut senada dengan apa yang disampaikan ibu $\mathrm{C}$ selaku anggota konseling kelompok melalui wawancara tanggal 22 September 2015:

"Pentingnya konseling kelompok agar dapat memberi dukungan kepada korban agar tidak merasa putus asa, malu, cemas, merasa sendirian, sekaligus menjadi kawan dalam menghadapi masa-sama sulit agar bisa kembali menemukan kepercayaan dirinya, dan membantu memperoleh pemahaman tentang diri sendiri dan masalahnya dengan membantu untuk memahami kelebihan dan kekurangan diri. Kemudian konselor membantu korban untuk membuat rencana kedepan akan tindakan apa yang perlu diambil untuk menghindari situasi kekerasan yang berlanjut dengan cara memberi informasi tentang hak korban agar mengetahui solusi yang dapat diambil, tidak sekedar diam dan pasrah menerima nasib". 50

Layanan bimbingan dan konseling yang dilakukan dalam bentuk dinamika kelompok dapat membantu individu belajar mengembangkan prilaku baru yang lebih produktif, efektif, dan positif atau mengembangkan kemampuan diri atas dasar kesadaran diri. Kelompok membantu individu memperoleh pengalaman dan masukan serta umpan balik yang bermakna. Kelompok juga membantu individu mengembangkan kerangka berfikir yang lebih dinamis, efektif, kreatif dan inovatif. ${ }^{51}$ Dalam proses konseling kelompok diperlukan komunikasi yang efektif, karena dengan komunikasi yg efektif: (1) pesan dapat tersampaikan dan dipahami dengan cara dan bahasa yang jelas, terstruktur, dan tidak menimbulkan penafsiran yang berbeda; (2) berlangsung dua arah; (3) menimbulkan saling pemahaman dan komitmen; serta (4) mendorong adanya relasi interpersonal yang sehat. ${ }^{52}$ Kemampuan dalam bidang kepemimpinan serta mengembangkan interaksi dinamis dalam kelompok diperlukan konselor untuk mengembangkan layanan bimbingan konseling yang komprehensif, sehingga bimbingan

${ }^{49}$ Prayitno dan Erman Amti, Dasar-dasar Bimbingan dan Konseling, h. 213.

${ }^{50}$ Wawancara dengan Ibu C, 22 September 2015.

${ }^{51}$ Mamat Supriatna, Bimbingan dan konseling berbasis kompetensi: orientasi dasar pengembangan, (Jakarta: Raja Grafindo, 2011), h. 250.

52 Ibid, h. 239. 
konseling menjadi pendukung utama dalam penanganan kekerasan dalam rumah tangga di LRC-KJHAM Semarang.

Dalam proses konseling kelompok (support group) penulis menilai adanya kekurangan dalam hal komunikasi efektif. Perlunya pendidikan pra konseling mengenai komunikasi yang efektif dapat menyelesaikan masalah lebih cepat, komunikasi yang terhambat membuat respon yang diberikan oleh komunikan terhadap komunikator tidak menyenangkan. Hambatan dalam berkomunikasi dikelompokkan pada tiga kelompok yaitu: menilai, memberikan solusi, dan memberikan perhatian yang berbeda. Menilai adalah memberikan respon dengan memberikan penilaian, terhadap pesan yang disampaikan, dengan cara memberikan evaluasi baik terhadap komunikator. Memberi solusi adalah memberikan komentar atau respon segera terhadap problem yang disampaikan oleh komunikator tanpa pertimbangan matang dan sering menimbulkan masalah baru. Memberikan perhatian yang berbeda adalah memberikan respon untuk memperpanjang pembicaraan dengan cara menyampaikan atau menceritakan pengalaman/ pengetahuan/ informasi sendiri yang berkaitan dengan topik pembicaraan, memberikan argumen yang logis, memberikan komentar yang bertolak belakang dengan isi pesan komunikator sebagai pembenaran..$^{53}$

Penanganan melalui bimbingan konseling dalam menangani perempuan korban kekerasan dalam rumah tangga di LRC-KJHAM melalui konseling secara individu dan kelompok (support group) ternyata menimbulkan perubahan yang signifikan dari perubahan sikap dan psikologis istri korban kekerasan dalam rumah tangga, dapat dilihat, isteri korban kekerasan dalam rumah tangga merasa terbantu dan lega setelah melalui proses penanganan tersebut.

Dari uraian penanganan perempuan korban KDRT di LRC-KJHAM, penulis dapat menyimpulkan bahwa LRC-KJHAM dalam menangani kasus perempuan korban KDRT berjalan dengan baik, walaupun di beberapa segi perlu peningkatan tetapi semuanya sudah berjalan dengan baik karena dalam proses penanganan selalu melakukan evaluasi menyeluruh, sehingga semua yang ditargetkan bisa tercapai dan berjalan sesuai dengan apa yang direncanakan.

\footnotetext{
${ }^{53}$ Ibid.
} 


\section{F. Kesimpulan}

Persoalan kekerasan perempuan dalam rumah tangga menjadi salah satu kasus perlu mendapatkan perhatian dan penanganan serius. Pemerintah bersama masyarakat memiliki tanggung jawab untuk merespon dan menangani dampak akibat kekerasan tersebut. LRC KJHAM sebagai salah satu LSM di Jawa Tengah memiliki kepedulian dan program dalam penanganan kasus KDRT, salah satunya melalui layanan bimbingan dan konseling. Konseling dilakukan dengan bentuk konseling individual dan kelompok sebagai upaya untuk memberikan pemulihan dan penguatan dimensi psikhis dan mental korban. Layanan konseling tersebut dirasakan memiliki kontribusi positif bagi kesehatan mental korban/klien.[]

\section{Daftar Pustaka}

Amin, Samsul Munir, Bimbingan dan Konseling Islam, Jakarta: Amzah, 2010.

Arifin, Isep Zainal, Bimbingan Penyuluhan Islam. Jakarta: Raja Grafindo Persada, 2009.

Belkin, Gary. S., Introduction to Counseling, United States of America: Brown Company Publisher, 1984.

Faqih, Aunur Rahim, Bimbingan dan Konseling Dalam Islam. Yogyakarta: UII Press, 2004.

Gibson, Robert L dan Mitchell, Mariane H., Bimbingan dan Konseling. Yogyakarta: Pustaka Pelajar, 2011.

Hallen A., Bimbingan dan Konseling. Jakarta: Ciputat Press, 2005.

Jones, Principles of Giudance, Newn Delhi: Mc Graw Hill Publishing, 1979.

Kertamuda, E. Fatchiah, Konseling Pernikahan untuk Keluarga Indonesia, Jakarta: Salemba Humanika, 2009.

Komnas Perempuan, Catatan Tahunan. dalam www. Komnasperempuan.or.id/2004-kegentingan-kekerasan-seksual-lemahnyaupaya-penanganan-negara, di akses tanggal 15 Desember 2014, pukul 20.30.

LRC-KJHAM, Laporan Tahunan Kekerasan terhadap Perempuan Tahun 2013 Di Jawa Tengah, 2013. 
LRC-KJHAM, Profil dalam www.kjham.org/profil-lrc-kjham-semarang/02.25 di akses 11 Mei 2013, pukul 02.25.

Martha, Elmina Aroma, Perempuan dan Kekerasan Rumah tangga di Indonesia dan Malaysia. Yogyakarta: FH UII, 2012.

Mufidah, Psikologi Keluarga Islam Berwawasan Gender. Malang: UIN Malang Press, 2008

Naimah, "Pemikiran Agama dan Pemberdayaan: Rekonseptualisasi Perempuan Kepala keluarga", Jumal Dimas. Vol. 12 No. 2 Tahun 2012.

Nugroho, Aji. "Pemikiran Agama dan Pemberdayaan: Perempuan dan Kekerasan Mencari Surga dibawah Tangan Suami”, Jurnal Dimas. Vol. 13 No. 1 Tahun 2013.

Nurhayati, Eti, Psikologi Perempuan dalam Berbagai Perspektif. Yogyakarta: Pustaka Pelajar, 2012.

Nuhayati, Eti, Bimbingan, Konseling \& Psikoterapi Inovatif, Yogyakarta: Pustaka Pelajar, 2011.

Prayitno dan Erman Amti, Dasar-dasar Bimbingan dan Konseling, Jakarta: Rineka Cipta, 2013.

Pujosuwarno, Sayekti, Bimbingan dan Konseling Keluarga. Yogyakarta: Menara Mas Offset, 1994.

Samadani, Adil, Kompeten si Pengadilan Agama Terhadap Tindak Kekerasan dalam Rumah tangga, Yogyakarta: Graha Ilmu, 2013.

Supriatna, Mamat, Bimbingan dan Konseling berbasis kompetensi: orientasi dasar pengembangan, Jakarta: Raja Grafindo, 2011.

Suhandjati, Sri, Islam Menentang Kekerasan terhadap Istri, Yogyakarta: Gamma Media, 2004.

Sutoyo, Anwar, Bimbingan dan Konseling Islam (Teori dan Praktif), Yogyakarta: Pustaka Pelajar, 2013.

Undang-Undang Republik Indonesia Nomor 23 Tahun 2004 tentang Penghapusan Kekerasan Dalam Rumah Tangga, Jakarta: Laksana Mandiri, 2004.

Walgito, Bimo, Bimbingan dan Konseling Perkawinan, Yogyakarta: Andi Offest, 2004.

www.komnasperempuan.or.id/2004/11catatan-tahunan-komnas-perempuan20014-kegentingan-kekerasan-seksual-lemahnya-upaya-penanganan-negara/ di akses tanggal 15 desember 2014, pukul 20.30. 
